\title{
Ostensiewe illustrasies as mikrostrukturele items in verklarende skoolwoordeboeke gerig op leerders in die junior sekondêre fase
}

Phillip Louw, Buro van die Woordeboek van die Afrikaanse Taal, Stellenbosch en Departement Afrikaans en Nederlands, Universiteit van Stellenbosch, Stellenbosch, Republiek van Suid-Afrika (pal@sun.ac.za).

Opsomming: 'n Verklarende skoolwoordeboek gerig op leerders in die junior sekondêre fase moet, in die Suid-Afrikaanse konteks, gebruikersgerigte praktyke navolg om op kommunikatiewe en pedagogiese vlak waarde toe te voeg vir beide moedertaal- en niemoedertaalsprekende leerders. Een so ' $n$ praktyk is die opname van ostensiewe illustrasies as mikrostrukturele items om die oordrag van pragmatiese en semantiese data te bevorder. In hierdie artikel word die waarde van ostensiewe illustrasies en hulle relevansie binne 'n verklarende skoolwoordeboek gerig op leerders in die junior sekondêre fase beoordeel, waarna sekere voorbehoude rakende hulle gebruik behandel word. ' $n$ Besluit om wel ostensiewe illustrasies op te neem, noodsaak verder 'n bespreking van waar om hierdie items in die mikrostruktuur te plaas sowel as 'n bespreking van verskillende tipes illustrasies wat vir opname in die woordeboektipe onder bespreking geskik sal wees. Vervolgens word ' $n$ kritiese evaluering van die hantering van ostensiewe illustrasies in ' $n$ eg Suid-Afrikaanse verklarende skoolwoordeboek gerig op leerders in die junior sekondêre fase gegee en voorstelle gemaak vir 'n verbeterde mikrostrukturele behandeling wat aan die eise van die gebruikersperspektief voldoen. Laastens word die kwessie van noodsaaklike mediostrukturele ondersteuning vir hierdie datatipe in die vorm van presiese, omvattende kruisverwysings, ter sprake gebring. Hierdie artikel probeer dus om kriteria vir die suksesvolle leksikografiese hantering van ostensiewe illustrasies aan te bied.

Sleutelwoorde: BYSKRIFTE, BYVOEGLIKE NAAMWOORD, GROEPILLUSTRASIE, JUNIOR SÊKONDERE ONDERRIGFASE, KOMMUNIKATIEWE WAARDE, KRUISVERWYSINGS, MIKROSTRUKTURELE ITEMS, OSTENSIEWE ILLUSTRASIES, PEDAGOGIESE WAARDE, SELFSTANDIGE NAAMWOORD, STRUKTUURMERKERS, VERKLARENDE SKOOLWOORDEBOEK, VOORBEELDMATERIAAL, WERKWOORD

Abstract: Ostensive Illustrations as Microstructural Items in Explanatory School Dictionaries Targeting Learners in the Junior Secondary Phase. An

* $\quad$ Hierdie artikel is ' $n$ vertaling en verwerking van 'n hoofstuk uit 'n D.Litt.-proefskrif Criteria for a Multifunctional, Monolingual Dictionary in Junior Secondary Education, wat in April 2004 deur die Universiteit van Stellenbosch, Stellenbosch, Republiek van Suid-Afrika, aanvaar is.

Lexikos 15 (AFRILEX-reeks/series 15: 2005): 90-101 
explanatory school dictionary targeting learners in the junior secondary phase must, in the South African context, pursue user-oriented practices in order to add value for both mother-tongue- and non-mother-tongue-speaking learners on a communicative and a pedagogical level. One such practice would be the inclusion of ostensive illustrations as microstructural items in order to enhance the transfer of pragmatic and semantic data. In this article, the value of ostensive illustrations and their relevance in an explanatory school dictionary targeting learners in the junior secondary phase are evaluated, after which certain reservations regarding their use are addressed. A decision on whether to include ostensive illustrations demands a further discussion of where to position these items in the microstructure, as well as a discussion of different types of illustrations that will be suitable for inclusion in the type of dictionary profiled. Thereafter a critical evaluation of the treatment of ostensive illustrations in a genuinely South African explanatory school dictionary targeting learners in the junior secondary phase is provided and suggestions made for an improved microstructural treatment that meets the demands set by the user perspective. Lastly, the issue of necessary mediostructural support for this data type in the form of precise, comprehensive crossreferences will be raised. This article aims to present criteria for the successful lexicographical treatment of ostensive illustrations.

Keywords: ADJECTIVE, CAPTIONS, COMMUNICATIVE VALUE, CROSS-REFERENCES, EXAMPLE MATERIAL, EXPLANATORY SCHOOL DICTIONARY, GROUP ILLUSTRATION, JUNIOR SECONDARY EDUCATIONAL PHASE, MICROSTRUCTURAL ITEMS, NOUN, OSTENSIVE ILLUSTRATIONS, PEDAGOGICAL VALUE, STRUCTURAL INDICATOR, VERB

\section{Inleiding}

Die junior sekondêre onderrigfase is sonder twyfel deurslaggewend in die taalverwerwingsproses, hetsy in die verbreding van die beheersing van die moedertaal, of, veral in die Suid-Afrikaanse konteks, in die vaslegging van die tweede taal (dikwels Engels) en uitbreiding van die taalvermoë daarin om die leerder in staat te stel om daardie tweede taal as onderrigmedium effektief te ontsluit. In hierdie proses speel die gebruik van innoverende, effektiewe taalhulpmiddels 'n rol van kardinale belang. 'n Verklarende woordeboek wat pasgemaak is om aan die behoeftes van leerders (beide moedertaal- en niemoedertaalsprekers) in die junior sekondêre fase te voldoen, is een so 'n hulpmiddel.

Buiten hierdie belangrike kommunikatiewe funksie sal so 'n woordeboek ook noodwendig 'n refleksiewe leksikografiese funksie moet vervul. Vir baie leerders sal hierdie fase die eerste wees waartydens die oordrag van woordeboekgebruiksvaardighede deel uitmaak van spesifieke programme. So 'n woordeboek moet dus bruikbaar wees in 'n klaskameropset om die leerders voor te berei om lewenslange gebruikers van standaard- verklarende woordeboeke te wees. Om aan hierdie kriterium te voldoen, moet innovasie opgeweeg word teen leksikografiese tradisie en 'n balans verkry word sonder om die gebruikersperspektief uit die oog te verloor.

Een leksikografiese praktyk waarvan die kommunikatiewe en pedagogiese waarde nie onderbeklemtoon kan word nie, is die benutting van ostensiewe illustrasies (sien die afdeling "Die waarde van ostensiewe illustrasies" hieron- 
der). Hierdie praktyk neem ook die gebruikersperspektief in ag. 'n Steekproef wat onlangs deur die skrywer in drie multikulturele skole met 107 moedertaalen niemoedertaalsprekende leerders van Engels in grade agt en nege onderneem is, het sterk daarop gedui dat hierdie leerders verwag dat 'n verklarende woordeboek wat op hulle gerig is, ostensiewe illustrasies sal insluit om die verbale inligtingsoordrag aan te vul $(74 \%$ van die respondente was ten gunste daarvan). Dit is dus vreemd dat slegs een Suid-Afrikaanse verklarende skoolwoordeboek, naamlik die Chambers-Macmillan South African Dictionary Junior Secondary (voortaan SADJS), wat spesifiek op leerders in hierdie onderrigfase gerig is, wel ostensiewe illustrasies op 'n konsekwente basis benut, veral gegewe die waarde wat hierdie items kan toevoeg.

\section{Die waarde van ostensiewe illustrasies}

Ostensiewe illustrasies kan ingesluit word as mikrostrukturele items en kan ' $n$ baie belangrike rol vervul deur "visual support for the description of the meaning content of linguistic units" (Svensén 1993: 167) te verskaf. Illustrasies is van besondere belang in ' $n$ skoolwoordeboek, selfs in een wat leerders in die junior sekondêre fase as teikenmark het. Svensén (1993: 167-168) beskryf die opvoedkundige kriterium vir insluiting soos volg: "A picture reinforces learning, and also a picture may often, quite differently from a definition, appeal to the reader's previous experience of the world, and enable him to achieve fresh insights." Omdat illustrasies oor die vermoë beskik om 'n vroeëre ervaring met 'n bepaalde voorwerp, konsep, e.s.m. beter as ' $n$ item wat 'n betekenisparafrasering bied, te heraktiveer, voeg hy (1993: 168) by dat "illustrations are therefore more important in children's dictionaries than in dictionaries for adults".

\section{Voorbehoude rakende die gebruik van ostensiewe illustrasies}

Daar is sekere voorbehoude rakende die insluiting van illustrasies in 'n verklarende skoolwoordeboek wat op leerders in die junior sekondêre fase gerig is. Daar kan vernaamlik geredeneer word dat "they are rather space consuming" (Bogaards 1999: 122) en daarmee saam dus duur. Moontlike teenargumente is dat illustrasies egter die gebruikersvriendelikheid en opvoedkundige waarde van 'n skoolwoordeboek beduidend verbeter en dat, soos Svensén (1993: 167) aanvoer, hulle ruimte kan spaar "in many cases where a purely verbal description would have to be very detailed".

Nog 'n argument wat dikwels teen die insluiting van illustrasies aangevoer word, is dat hulle neig om die lading van ensiklopediese data in die woordeboek te verhoog. Gouws (1994: 69-71) het egter aangetoon dat hierdie kritiek hoofsaaklik ontstaan het weens die ondeurdagte gebruik van illustrasies in sommige verklarende woordeboeke, waar hulle nie dien om die verbale inligtingsoordrag aan te vul nie, maar eerder om dit te herhaal. Hy (1994: 69) wys 
duidelik daarop dat ' $n$ mate van ensiklopediese data nie noodwendig onaanvaarbaar is nie en dat die gebruik van illustrasies teen die agtergrond van die "toelaatbare ensiklopediese belading" van die spesifieke woordeboek gesien moet word. Daar kan geredeneer word dat illustrasies in 'n verklarende skoolwoordeboek gerig op leerders in die junior sekondêre fase ingesluit kan word, nie net weens hulle opvoedkundige waarde nie, maar ook weens die doeltreffende wyse waarop hulle meer van die ensiklopediese voorwerp-konstituerende kennis van 'n spesifieke leksikale item reflekteer. Sorg moet egter gedra word om nie te veel van die data wat reeds in die betekenisparafrasering van ' $n$ item en in die voorbeeldmateriaal aangebied is, te herhaal nie.

Bogaards (1999: 122) noem nog 'n potensiële nadeel van illustrasies wat leksikograwe noop om versigtig te werk te gaan, naamlik "it is difficult to find pictures which are clear to learners with very different cultural backgrounds and which at the same time conserve a flavour of authenticity". Die samestellers van 'n Suid-Afrikaanse verklarende skoolwoordeboek gerig op leerders in die junior sekondêre fase het wel in hierdie opsig 'n voordeel, naamlik dat hulle woordeboek Suid-Afrikaanse leerders teiken. Daar is moontlik 'n hoë mate van kulturele diversiteit in hierdie teikengroep en meer navorsing moet gedoen word om vas te stel of hierdie kulturele groeperings die tipes voorwerpe, handelings en beskrywende items wat ostensief geillustreer word, kan konseptualiseer. Daar is egter 'n sterk saak uit te maak dat daar 'n gedeelde SuidAfrikaanse ervaring en gevolglik 'n gedeelde Suid-Afrikaanse kulturele identiteit bestaan, wat deur die samestellers van 'n Suid-Afrikaanse verklarende skoolwoordeboek gereflekteer moet word. SADJS blyk 'n gebalanseerde benadering te volg deur generiese illustrasies en illustrasies wat in besonder relevant vir Suid-Afrikaanse leerders is, af te wissel. Die insluiting van illustrasies van baie diere wat uitsluitlik of veral in Suid-Afrika voorkom en die insluiting van ' $n$ illustrasie van 'n AK 47-aanvalsgeweer in die groepillustrasie by gun bied voorbeelde van die samestellers se verbintenis daartoe om die illustrasies relevant vir Suid-Afrikaanse leerders te maak.

\section{Die plasing van ostensiewe illustrasies in verklarende skoolwoorde- boeke gerig op leerders in die junior sekondêre fase}

Indien besluit is om wel illustrasies te verskaf, moet ernstige oorweging geskenk word aan waar hierdie illustrasies geplaas moet word. Die plasing van illustrasies word hoofsaaklik deur hulle aard en die tipologiese profiel van die woordeboek bepaal. Groot prente met 'n komplekse stel byskrifte word goed benut in die agterwerk van die Reader's Digest Afrikaans-Engelse Woordeboek/ English-Afrikaans Dictionary, 'n tweerigting- vertalende gesinswoordeboek, en blyk veral nuttig te wees om die struikelblok van insluiting in beide kante van 'n tweetalige woordeboek te oorkom. In 'n eentalig verklarende skoolwoordeboek, waarin groot prente onprakties en die nadruk op die onmiddellikheid van inligtingsoordrag is, kan geredeneer word dat kleiner illustrasies wat inge- 
sluit word as mikrostrukturele items met óf een, óf 'n paar bepaalde lemmas as adres(se), sowel bekostigbaar as doeltreffend is.

In die setproses moet egter noukeurig daarop gelet word dat hierdie illustrasies naby die lemma (of betekenisonderskeiding) wat die adres daarvan is, geplaas word, en, indien hulle meer as een lemma as adres het, moet die samestellers verseker dat toereikende artikel-eksterne kruisverwysings sneltoegang na beide die teikeninskrywing en, van daar af, na die relevante illustrasie bewerkstellig.

\section{'n Klassifikasie van tipes ostensiewe illustrasies}

Die besluit om kleiner illustrasies in die mikrostruktuur op te neem, verg versigtige beplanning rakende watter tipes ostensiewe illustrasies om in te sluit. Dit val nie binne die reikwydte van hierdie artikel om 'n omvattende tipologie van ostensiewe illustrasies te bied nie. Aspekte van sodanige tipologieë (soos in o.a. Svensén (1993: 171-178) en Ilson (1987: 193-199) vervat) sal egter benut word in die volgende kort bespreking oor gekose en geskikte illustrasietipes in 'n SuidAfrikaanse verklarende skoolwoordeboek gerig op leerders in die junior sekondêre fase.

'n Moontlike beginpunt in die bepaling van watter tipes illustrasies om te benut, sou wees om te besluit watter woordsoorte ostensiewe beligting sou benodig. Hierdie potensiële klassifikasie is bloot van praktiese waarde vir die leksikograaf, aangesien dit 'n maklik klassifiseerbare vertrekpunt in die woordeboekontwerpproses bied. Die effektiwiteit van ander klassifikasiestelsels kan in die aanloop tot die woordeboekontwerpfase ondersoek word.

Aangesien selfstandige naamwoorde die primêre woordsoort is wat vir ostensiewe beligting gemerk is, moet ' $n$ meer gedetailleerde bespreking van selfstandige naamwoorde volg. Tog kan ostensiewe illustrasies ook benut word by ander woordsoorte, veral by byvoeglike naamwoorde en werkwoorde.

Byvoeglike naamwoorde wat 'n stel antonieme of 'n komplementêre paar uitmaak (lank $x$ kort, dik $x$ dun, e.s.m.) kan goed deur middel van 'n prent geïllustreer word, mits die illustrasie maklik dekodeerbaar is en daar toereikende kruisverwysings is na die korrekte lemmas of betekenisonderskeidings waarop die illustrasie van toepassing is. Die sukses van die illustrasie van byvoeglike naamwoorde hang egter (ten spyte van die leksikograaf se beste pogings om duidelikheid te verseker) in 'n sekere mate af van die gebruiker se vermoë om die abstrakte verhouding tussen die prent en die leksikale item(s) wat dit probeer illustreer, te interpreteer, bv. dat die illustrasie van twee seuns van wisselende lengtes wat langs mekaar staan, die verskil tussen lank en kort kan verklaar. Ilson (1987: 198) maak dus 'n geldige punt: "a verbal explanation is a necessary complement to the picture."

Daar is ook "a risk of misunderstanding" (Svensén 1993: 178) in gevalle waar werkwoorde van ostensiewe illustrasies voorsien word. Waar die presiese verwysing van die illustrasie nie voldoende duidelik gemaak word nie, kan die 
gebruiker maklik die fout begaan om aan te neem dat een van die selfstandige naamwoorde die fokuspunt in die illustrasie is, eerder as die handeling wat uitgebeeld word.

Selfstandige naamwoorde sal die fokuspunte van die meeste illustrasies uitmaak en kan op verskeie maniere weergegee word. In 'n relatief klein skoolwoordeboek kan 'n mens verwag dat die meeste ostensiewe illustrasies in die mikrostruktuur net "one object of the kind concerned, without comment" sal vertoon. 'n Mens moet dan aanneem dat "the one shown is representative of its class" (Svensén 1993: 171). Ten spyte van die voor die hand liggende beperkings op ruimte, is daar tog ook drie ander illustrasietipes wat effektief kan optree as mikrostrukturele items in 'n kompakte Suid-Afrikaanse verklarende skoolwoordeboek gerig op leerders in die junior sekondêre fase. Svensén (1993: 172-174) identifiseer hierdie tipes as illustrasies wat "several objects of the same class", dié wat "an object in its surroundings", en dié wat "objects in operation" uitbeeld. Al vier hierdie illustrasietipes is teenwoordig in SADJS.

\section{Die gebruik van ostensiewe illustrasies in SADJS}

Terwyl 'n mededingende woordeboek soos The South African Oxford School Dictionary (wat dieselfde gebruikersgroep teiken) op ' $n$ minder visuele benadering besluit het en die ruimte daarin vir 'n meer omvattende makrostruktuur en meer verbale data in die mikrostruktuur benut, sluit SADJS wel ostensiewe illustrasies as mikrostrukturele items in. Die verbale inligtingsoordrag word by sommige byvoeglike naamwoorde en werkwoorde deur ostensiewe illustrasies aangevul, maar sulke illustrasies word gewoonlik vir selfstandige naamwoorde gereserveer.

Illustrasies word selde in SADJS by byvoeglike naamwoorde geplaas. Een so ' $n$ buitengewone voorkoms is ' $n$ illustrasie wat tussen die lemmas alternate en alternative geplaas is om die verskil tussen hierdie twee byvoeglike naamwoorde duidelik te maak. Hierdie voorstelling van 'n "contrast set" (Ilson 1987: 194) deur middel van 'n illustrasie hou tred met die organisasieteorie van SADJS soos uitgestippel in die "Introduction", waar gestel word dat "numerous illustrations throughout the text help the reader ... to distinguish between things that could easily be confused" (SADJS, p. v).

Die benadering om ' $n$ illustrasie wat uit twee of meer kleiner prente bestaan, te benut om 'n onderskeid tussen verwarbare woorde te tref, word ook by sommige werkwoorde gebruik. Daar is byvoorbeeld illustrasies by bring (om 'n onderskeid tussen bring, take en fetch te tref), lay (om te onderskei tussen lay en lie) en mow (om te onderskei tussen mow, harvest/reap en trim). SADJS slaag hoofsaaklik in die doel van ondubbelsinnigmaking as gevolg van twee belangrike besluite wat deur die samesteller(s) geneem is.

Eerstens, illustrasies tree in wisselwerking met die ingevoegde binnetekste (gebruiksnotas) in getinte tekskassies op wat die "verbale" komplementering verskaf wat Ilson (1987: 198) as 'n voorvereiste in sulke gevalle stel. Hierdie in- 
gevoegde verbale binnetekste is op hulle eie alreeds ' $n$ kragtige medium om tussen verwarbare leksikale items te onderskei, maar indien hulle saam met die illustrasies gebruik word, word die gebruikersvriendelikheid van die woordeboek verbeter, veral vir minder bedrewe gebruikers.

Tweedens maak SADJS van verwyderde artikel-eksterne kruisverwysings gebruik om te verseker dat dié gebruiker wat byvoorbeeld lie opsoek, vinnig en doeltreffend na die illustrasie en meegaande gebruiksnota by lay gestuur word. Hierdie kruisverwysings word ook in getinte tekskassies aangebied, en hoewel hulle nie heeltemal doeltreffend is nie (hulle waarde word onder meer verminder deurdat dieselfde tipe kruisverwysing ook gebruik word om die gebruiker te rig op 'n paar verbale ingevoegde tekste wat 'n ondubbelsinnigmakende funksie het, en hulle dus nie unieke verwysing bied nie), verskaf hulle waardevolle hulp aan die teikengebruiker (sien die afdeling oor "Illustrasies en kruisverwysings" hieronder vir 'n verdere bespreking van hierdie stelsel se tekortkominge).

Dieselfde benadering word gevolg wanneer ' $n$ onderskeid tussen twee of meer selfstandige naamwoorde getref moet word (sien die illustrasies by scissors, plait en nut). Tog is daar gevalle waarin illustrasies bloot "the reader (help) to identify objects" (SADJS, p. v). In hierdie verband bied Svensén (1993: 171-174) se vier illustrasietipes 'n nuttige raamwerk om SADJS se illustrasies te evalueer.

Sommige enkelvoorwerpe word in SADJS geillustreer, maar daar word nooit verduidelik wat die kriteria vir insluiting is nie. Talle bokspesies, asook ander diere soos 'n gorilla en tarentaal word by die relevante lemmas uitgebeeld, maar dit is nie die geval met ander diere soos ' $n$ sjimpansee, kameelperd, olifant, leeu en pou nie. Hierdie inkonsekwentheid is ook teenwoordig in die uitbeelding van ander tipes voorwerpe en getuig van 'n gebrek aan versigtige beplanning.

'n Verdere moontlike punt van kritiek rakende SADJS se illustrasies van enkelvoorwerpe is dat die illustrasies in sommige gevalle te gedetailleerd is, met die gevolg dat dit nie altyd vir alle gebruikers duidelik is wat eintlik uitgebeeld word nie. In die illustrasie van dashboard word 'n stuurwiel ook aangetoon en by dinghy (sien Illustrasie 1) is 'n roeispaan ook aanwesig.

\section{Illustrasie 1}

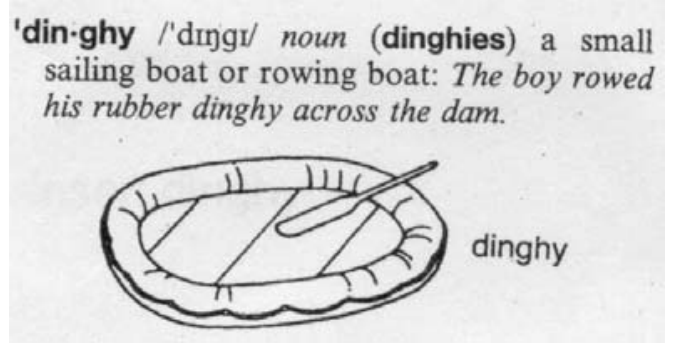


Gedetailleerde byskrifte of ' $n$ verbale komplement moet benut word om te verseker dat daar geen risiko van 'n misverstand is nie.

Bykomend tot illustrasies van enkelvoorwerpe sluit SADJS ook groepillustrasies van verskeie hiponieme in, gewoonlik by 'n geskikte superordinaat. By instrument (sien Illustrasie 2), byvoorbeeld, bied ' $n$ volbladgroepillustrasie van verskeie musiekinstrumente met 'n byskrif by elk van die komponente, ' $n$ goeie oorsig oor die "klas" waartoe hierdie voorwerpe behoort. Hier vertoon die illustrasie kenmerke van die sinopsisartikel, aangesien dit vinnige toegang tot hiponieme bied deur hulle by die superordinaat uit te beeld.

\section{Illustrasie 2}

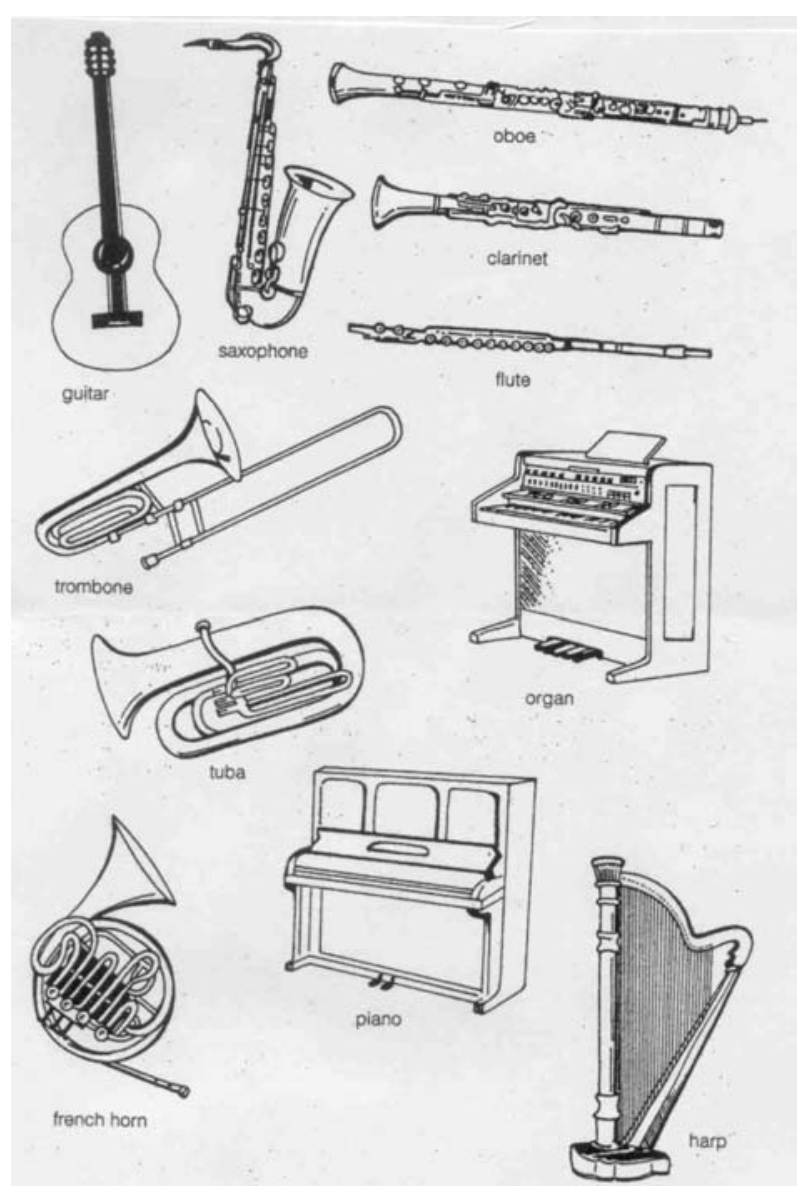

Daar is egter 'n tekortkoming in SADJS se behandeling van hierdie illustrasies. Anders as wat die geval was met die benadering tot illustrasies wat daarop gemik is om tussen verwarbare leksikale items te onderskei, skiet die deurslaggewende mediostrukturele ondersteuning by instrument tekort. Daar is geen 
kruisverwysings met die groepillustrasie as teiken by enige van die lemmas wat die hiponieme (bv. harp) wat in hierdie groepillustrasie uitgebeeld word, verteenwoordig nie. Dit verlaag die waarde van SADJS se gebruik van illustrasies as ' $n$ effektiewe hulpmiddel by die leksikografiese behandeling van hiponimie.

SADJS sluit ook illustrasies van "an object ... shown in its normal environment" (Svensén 1993: 173) in. By iris (sien Illustrasie 3) word byvoorbeeld ' $n$ illustrasie aangebied wat die iris van ander dele van die oog (bv. die kornea en die pupil) en van omliggende kenmerke soos die wenkbrou onderskei.

\section{Illustrasie 3}

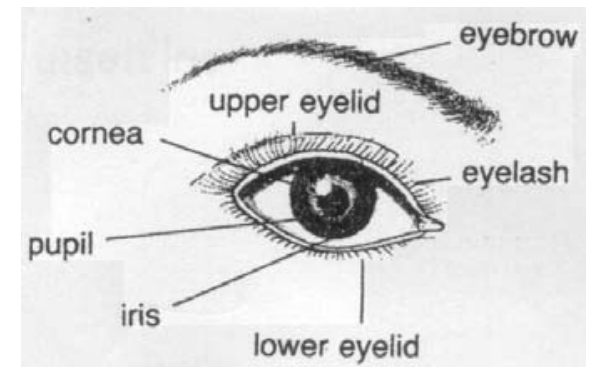

Hierdie illustrasie is besonder suksesvol omdat die byskrifte en hulle verwysingspunte duidelik gegee word en omdat daar gedetailleerde kruisverwysings is by elk van die lemmas wat met die beskrywings ooreenstem. By horn (sien Illustrasie 4) is die prosedure egter minder deeglik. Geen byskrifte word aangebied om die horings van die nek en kop (en samestellende dele daarvan) van die bok wat hier geillustreer is, te onderskei nie.

\section{Illustrasie 4}

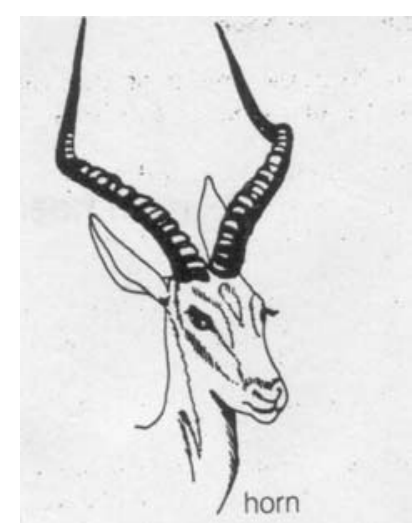

Dit strook duidelik nie met Svensén (1993: 173) se hoofkriterium vir die behandeling van sulke gevalle nie, d.w.s. dat die "object ... must be plainly distinguishable". 
Laastens bied SADJS 'n paar illustrasies van voorwerpe in werking. Hulle word sorgvuldig gekies en gewoonlik goed saamgestel (bv. die illustrasie van 'n vulkaniese uitbarsting by volcano). In sommige gevalle is die illustrasies egter te klein en te gedetailleerd (bv. by rapid (sien Illustrasie 5)), wat, ten spyte van 'n goeie stelsel van byskrifte, tot verwarring aanleiding kan gee.

\section{Illustrasie 5}

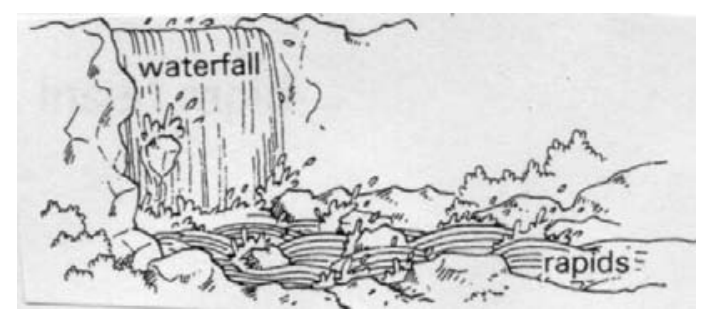

\section{Illustrasies en kruisverwysings}

Soos reeds vermeld, bied die plasing van illustrasies in die agterwerk oplossings vir heelwat van die probleme van die samesteller(s) van ' $n$ tweerigtingvertalende woordeboek, maar in die geval van 'n verklarende skoolwoordeboek gerig op leerders in die junior sekondêre fase is, soos in die afdelings hierbo voorgestel, insluiting van illustrasies by of naby aan die relevante lemmas ' $n$ meer koste-effektiewe opsie wat inligting onmiddellik beskikbaar stel. Die sukses van so 'n stelsel hang egter grootliks van die mediostruktuur af en in dié verband is daar bykomende lesse te leer uit die suksesse en foute van SADJS. Eerstens moet die byskrifte van illustrasies waarvan die teikenlemma polisemies is, met groot sorg hanteer word. By sommige gevalle in SADJS (sien bv. bed) word die probleem van verwyderde adressering opgelos deur die illustrasie net na die relevante betekenisonderskeiding in te sluit. Dit maak die gebruik van kruisverwysings onnodig en behoort, waar moontlik, ook in 'n Suid-Afrikaanse verklarende skoolwoordeboek gerig op leerders in die junior sekondêre fase benut te word. SADJS pas egter nie hierdie benadering konsekwent toe nie (sien bv. earth (Illustrasie 6)).

\section{Illustrasie 6}

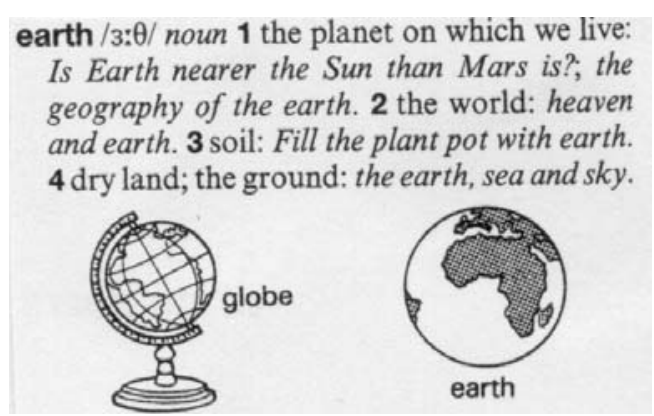


' $n$ Benadering wat onmiddellike adressering bied, is nie in alle gevalle toepaslik nie. Die illustrasie kan te groot wees (soos in die volgende paragraaf uitgewys sal word) en kan derhalwe die kohesie van die mikrostruktuur onderbreek en word daarom aan die einde (en soms in die nabyheid) van die relevante artikel aangebied. In gevalle waar die lemma polisemies is, is dit belangrik dat die byskrifte as presiese kruisverwysings optree wat die gebruiker lei na die presiese betekenisonderskeiding wat in die illustrasie uitgebeeld word. Sulke presiese kruisverwysings word nie in SADJS toegepas nie, wat veroorsaak dat komplekse, verwyderde adresseringsprosedures gevolg moet word, sonder dat voldoende items wat sekondêre adresse aandui, as gidse verskaf word.

Om ruimte te bespaar en onomasiologiese verhoudings tussen lemmas te bewerkstellig, word groot groepillustrasies dikwels by 'n lemma aangebied wat 'n superordinaat verteenwoordig. Soos duidelik behoort te blyk uit die vorige paragraaf, behoort die byskrifte baie presiese kruisverwysings te wees wat die gebruiker lei na die relevante betekenisonderskeiding van enige van die lemmas wat in die illustrasie uitgebeeld word. Hierdie kruisverwysings moet egter deur ' $n$ ewe presiese en duidelike verwysingsinskrywing in die mikrostrukuur van die relevante artikel aangevul word.

SADJS bied wel kruisverwysings om met die byskrifte ooreen te stem. Hulle word in getinte tekskassies teen die einde van elke relevante betekenisonderskeiding of artikel aangebied en kom in die vorm van 'n vet gedrukte kruisverwysing voorafgegaan deur die mediostrukturele merker "See" voor. Daar kan egter gevra word of hierdie kruisverwysings hulle rol bevredigend vertolk. In hulle huidige formaat word hulle tussen die ingevoegde binnetekste wat pragmatiese en grammatikale data bied, genes. In 'n lang artikel soos each, is die kruisverwysing een van vier getinte tekskassies en daar kan geargumenteer word dat die tekskassie as struktuurmerker nie prominent genoeg is om vinnige toegang tot die kruisverwysing te verseker nie. In hierdie verband is die unieke merker wat deur CIDE benut word, miskien 'n beter opsie. By die lemma hip fruit word die volgende item wat die kruisverwysing gee, aangebied: [PIC Berries. Tipografiese en nietipografiese struktuurmerkers kombineer om 'n suksesvolle kruisverwysing te bewerkstellig na die collage wat naby berry geplaas is en waarin die prentjie van rose hip voorkom. Die pyl (nietipografies) en die hoofletters PIC as 'n afkorting van "picture" kombineer met die aanbieding van Berries in vet druk en 'n ander druktipe om 'n prominente, unieke en maklik identifiseerbare verwysingsinskrywing te skep. Hierdie uitstekende metode, of soortgelyke markering, kan met vrug benut word in ' $n$ Suid-Afrikaanse verklarende skoolwoordeboek gerig op leerders in die junior sekondêre fase.

\section{Samevatting}

Illustrasies sal 'n belangrike rol in die ondersteuning van die oordrag van pragmatiese en selfs semantiese data in 'n Suid-Afrikaanse verklarende skoolwoor- 
deboek gerig op leerders in die junior sekondêre fase speel. Groter sorg moet egter bestee word as wat die geval was in SADJS. Alle tipes illustrasies in so ' $n$ skoolwoordeboek moet voldoen aan die beginsels van duidelikheid, omvattende behandeling en presiese kruisverwysing, soos in die voorafgaande evaluering van SADJS uitgestippel is.

\section{Bibliografie}

\section{Woordeboeke}

Chambers-Macmillan. 1996. Chambers-Macmillan South African Dictionary Junior Secondary. Manzini: Macmillan Boleswa Uitgewers.

Grobbelaar, P. (Red.). 1987. Reader's Digest Afrikaans-Engelse Woordeboek/English-Afrikaans Dictionary. Kaapstad: The Reader's Digest Association.

Hawkins, J.M. 1996. The South African Oxford School Dictionary. Kaapstad: Oxford University Press.

Procter, P., et al (Eds.). 1995. Cambridge International Dictionary of English. Cambridge: Cambridge University Press.

\section{Ander bronne}

Bogaards, P. 1999. Access Structures of Learners' Dictionaries. Herbst, T. en K. Popp (Reds.). 1999. The Perfect Learner's Dictionary (?): 113-130. Tübingen: Max Niemeyer Verlag.

Gouws, R.H. 1994. Ostensiewe adressering in vertalende woordeboeke. Lexikos 4: 61-85.

Ilson, R. 1987. Illustrations in Dictionaries. Cowie, A. (Red.). 1987. The Dictionary and the Language Learner: 193-212. Tübingen: Max Niemeyer Verlag.

Svensén, Bo. 1993. Practical Lexicography: Principles and Methods of Dictionary-Making. Oxford: Oxford University Press. 